MURAT DARÇIN, Ph.D.

E-mail: mrtdrc@yahoo.com

MURAT ALKAN, Ph.D.

E-mail: muratalkan95@yahoo.com

Ministry of Interior Affairs

06650 Ankara, Turkey
Safety and Security in Traffic

Preliminary Communication

Accepted: July 6, 2014

Approved: July 8, 2015

\title{
SAFETY RISK OF MOBILE PHONE USE WHILE DRIVING IN SAMPLE OF TAXI DRIVERS
}

\begin{abstract}
Previous research has shown that mobile phone use while driving increases the risk of being involved in an accident. This paper investigates the reported frequency of taxi drivers' mobile phone use and its effects on traffic safety. A representative sample of taxi drivers was included in an interview-based survey by trained interviewers. It was found that $81 \%$ of the taxi drivers reported talking by using handheld phone while driving. There is a relationship between the phoning while driving and drivers' self-reported involvement in a dangerous situation. It is clear that the use of mobile phone while driving is an important traffic safety issue.
\end{abstract}

\section{KEY WORDS}

dangerous situation; mobile phones; risk taking; professional drivers; safety;

\section{INTRODUCTION}

Mobile phone ownership in many countries has been increasing rapidly. As an example, as of 2009 , $90 \%$ of the Turkish population subscribed to a mobile phone service [1]. The frequency of mobile phone use is quite high. Much of this use occurs while travelling in a motor vehicle.The proportion of drivers who use the phone while driving varies according to the country, the year and the law about phoning while driving [2-8]. The increasing use of mobile phones, especially among professional drivers (e.g. truck, bus or taxi drivers) represents a potential traffic safety problem. Professional drivers had the highest daily use among different categories of road users.

Experimental studies have shown that mobile phone use has a negative impact on driving performance [6, 9-12] in different areas such as vehicle control [13], attention [14, 15], workload [16], impaired eye scanning $[17,18]$, and reaction time [16, 19-22]. Despite the apparent evidence that mobile phone use while driving presents a risk to safety, many drivers recognize that the benefits outweigh the risks [23-26].
It is reported that mobile phone use while driving contributes to less than $1 \%$ of all traffic accidents [27]. It is difficult to assess what the real risk is since most drivers involved in car crashes would not report mobile phone use as an accident cause when other causes are evident [21, 28].

Using mobile phone, talking or both sending and receiving text-messages while driving greatly increase the risk of drivers being involved in a crash $[9,28]$. Epidemiological studies have shown that $1 \mathrm{~h}$ per month of cell phone use while driving is associated with a 400-900\% increase in the likelihood of driver's crash risk [29-31]. The risk of crash during cell phone conversations is greater than the risk when driving with an alcohol amount exceeding the legal alcohol limits for drivers in many countries [32, 33].

Although drivers believe hands-free device is safer than using hand-held phone [34], several studies have indicated that hands-free use does not have any safety advantage over hand-held use $[4,6,11,22,31$, 3538]. In Turkey and many countries, laws ban hand-held phones while driving but allow hands-free phones, although there is no evidence that hands-free phones cause significantly less risk. Laws banning the use of hand-held mobile phone while driving do not reduce their use [12, 39]. Although some researchers have found that laws about banning mobile phone use while driving can reduce the use of phones while driving [11, 23 ] the effects of laws have been quite small.

The purpose of this study was to investigate the prevalence of mobile phone use among taxi drivers. It was hypothesized that mobile phone use while driving would be both a widespread and frequent activity among this group of drivers who perform a major part of their working day activity by using mobile phone in a vehicle. The link between mobile phone use and traffic safety was investigated through the drivers' self-reported involvement in accidents and dangerous situations while using mobile phones. Another purpose of this study was to explore how often taxi drivers talk on a mobile phone while driving, and what factors 
influence them to do this. The impact of demographic characteristics on taxi drivers' decision of mobile phone use while driving was also investigated in the present study. In addition, the research also examined the drivers' perception of risks involved in using a mobile phone while driving.

\section{METHOD}

\subsection{Participants and sampling}

There were 784 taxi drivers randomly chosen as the sample among 2,000 taxi drivers who work in taxi stations which are recorded under Ankara Public Drivers Union in Yenimahalle and Cankaya districts of Ankara/Turkey. These 784 drivers were contacted to apply for the questionnaire but only 327 of them accepted face-to-face conversation. Other drivers stated that they are willing to enroll but they cannot find free time for the research since they choose to work itinerantly in the city. Two professional visitor groups who accepted to have a face-to-face conversation with 327 drivers at randomly determined stations were formed. Each group consisted of two people. The first one asked the questions and the second one wrote notes about the answers given. Survey form and questions were not visible directly and the questionnaires tried to be applied in a usual daily conversation manner and therefore possible negative effects of the questionnaire tried to be diminished. Before the questionnaire was applied, every single taxi driver that would be interviewed was set apart from other drivers that were waiting to be interviewed. Time specified for each conversation was 20 minutes. First, drivers were informed about the purpose of the study and then they answered the questions. Every day, each group interviewed 12 drivers on the average. All conversations were completed in a period of 14 days randomly chosen in March and April (2013).

\subsection{Data}

The questionnaire consisted of 23 items and it was developed by choosing the questions among commonly accepted survey questions in similar studies, according to the goal of this research. The questionnaire was applied to the sample by professional specialists in the field of traffic and accident research, using faceto-face conversation methods.

The questionnaire consisted of three parts.

1) The purpose of the questionnaire;

2) Socio-demographic findings: Driver's age (AGE), gender, driving experience (EXP), the mobile phone ownership (OWN), education level (EDU) [elementary school (EDU1), junior high school (EDU2), high school (EDU3), and university], mar- ital status, occupational information, daily vehicle use (VECUSE), break time (BREAK) etc.

3) Questions related to the mobile phone use: The reasons of daily mobile phone use, the most called person (CALL), using mobile phone while driving (PHODRI) or not, not a police penalty as a result of mobile phone use while driving (POLICE1), dangerous or risky situations that they experienced while they were both driving and using mobile phone (DANGER), daily mobile phone use (PHOUSE), methods of their mobile phone use while driving [mobile phone / hand held mode (HELD1), hands-free mode or use with hand-set tool-kit], their habits about using or not using text messaging (SMS1) etc.

\subsection{Statistical procedures}

The $\mathrm{x}$ 2-test is used to analyze the effects of age, vehicle use time and penalty on phoning while driving. Relationship between phone use and traffic safety is also analyzed by using $x 2$-test. A significance level of 0.05 is adopted for the significance tests. Logistic regression was utilized to determine the effect of socio-demographic and behavioural variables on mobile phone use while driving and safety situations (not involved in danger) while driving.

\section{RESULTS}

\subsection{Descriptive statistics}

All of the respondents were males. The number of female taxi drivers in Ankara is fairly small and can be therefore ignored. Taxi drivers chosen to be the sample for this study were between 23 and 64 years old and among them: 181 between the ages 23 and 35, 83 between the ages 36 and 45 and 63 more than or equal to 46 years old. All of them had driver's license. Their average driving experience was 17 years. All drivers had personal cell phones and they stated that they regularly used these cell phones every day.

The first finding of the research was the high rate of mobile phone ownership in the sample. It is reported that $100 \%$ of the sample, the primary drivers of taxis, have a mobile phone. There were $81 \%$ of the taxi drivers who reported using hand-held or hands-free phones while driving at least some of the time.

Participants reported how likely they are to either answer or initiate a hand-held mobile phone conversation while driving and how likely they are to text message while driving. There were $81 \%$ of participants who reported talking by using hand-held phones and 32\% of participants reported text-messaging while driving at least some of the time. 


\subsection{Mobile phone use while driving}

There is a significant relationship between mobile phone use while driving and driver's age (chisquare=29.815; d.f.=1; $p<0.05$ ). In this study it is determined that while $60 \%$ of the drivers $(n=38$ in $63)$ whose ages are greater than or equal to 46 use mobile phone during driving, this ratio $(n=164$ in 181) exceeds $90 \%$ for the ones whose ages are between 23 and 35.

There were 45 of the 327 drivers (14\%) who enrolled in face-to-face meetings who stated that their daily vehicle use time is between 1 and 6 hours, 167 of the 327 drivers (51\%) stated that it varies between 7 and 9 hours and 115 of the 327 drivers (35\%) said that it is more than 10 hours. There is a significant dependency between mobile phone use while driving and daily vehicle use time (chi-square $=15.880$; d.f. $=2$; $p<0.05)$. Despite the fact that the drivers whose daily vehicle use time is the least (1-6 hours/day) account for $14 \%$ of the whole sample, the ratio of this group doubles among the ones who do not use mobile phone while driving. Seventeen of 45 (38\%) taxi drivers, who use their vehicles 1-6 hours per day, do not use mobile phones while driving. This ratio is only 12 of 115 (10\%) for the taxi drivers who use their vehicles more than 10 hours a day. This fact shows that as the daily vehicle use time decreases, the ratio of mobile phone use while driving decreases, too.

There is no relationship between mobile phone use while driving and police penalty as a result of mobile phone use while driving (chi-square=1.061; d.f. $=1 ; p>$ 0.05). $94 \%(n=249)$ of the mobile phone users while driving stated that they hd not been warned about the use of mobile phones while driving by traffic police before. $10 \%(n=6)$ of the mobile phone non-users while driving stated that they gave up using mobile phone while driving after they were warned about it by traffic police. In other words, $10 \%$ of these individuals had given up using the phone while driving because of having been warned. $73 \%(n=16)$ of the drivers who were warned by traffic police because of mobile phone use while driving $(n=22)$ did not change phone using behaviour while driving.

Daily mobile phone use time concerns the mobile phone use in everyday life. There is no dependency found between daily mobile phone use time and being warned by traffic police while both driving and using mobile phone at the same time (chi-square=1.047; d.f. $=2 ; p>0.05$ ).

\subsection{Involvement in dangerous situations while driving}

Use of mobile phones is more widespread among the younger drivers. The current study suggests no significant relationship between the driver's age and being involved in a dangerous situation while driving (chi-square=5.435; d.f. $=2 ; p>0.05$ ).

More than half of the drivers (51\%) who use mobile phones while driving stated that they were involved in a dangerous situation while driving. Only $30.6 \%$ of the sample who did NOT use a mobile phone while driving reported experiencing dangerous situations while driving and NOT phoning. There is a relationship between the phone use (talking, SMS etc.) while driving and drivers' self-reported involvement in a dangerous situation while driving (chi-square=8.615; d.f. $=1 ; p<$ 0.05). Such data show that mobile phone users while driving experience more relative risk than the others.

There is a relationship between daily mobile phone use and being involved in a dangerous situation in traffic while driving (chi-square=6.415; d.f. $=2 ; p<0.05$ ). $39 \%$ of the taxi drivers who spend 0 to 5 minutes on the phone, $50 \%$ of the taxi drivers who spend between 6 and 10 minutes and $56 \%$ of the taxi drivers who use phone more than 11 minutes every day stated that they were involved in dangerous situations while driving.

There is a significant correlation between the reported daily vehicle use time and being involved in dangerous situations while driving (chi-square=18.366; d.f. $=2 ; p<0.05$ ). The group that has 1 to 6 hours of daily vehicle use and includes $14 \%$ of drivers who enrolled in the study, corresponds to only $5 \%$ of drivers who were involved in dangerous situations in traffic and $22 \%$ of the drivers who were not involved in a dangerous situation in traffic. The ratio of being involved in a dangerous situation for taxi drivers who use vehicles more than 10 hours a day is $52 \%$. This ratio is the same for 7-9-hour group but for 1-6-hour group the ratio of being involved in a dangerous situation is only $17 \%$. This fact shows that as the daily vehicle use decreases, the ratio of involving dangerous situations in traffic diminishes. According to the taxi drivers' self-reported data they experienced more dangerous situations while using hand-held phones than using handsfree ones (chi-square $=22.238$; d.f. $=1 ; p<0.05$ ). A graphical representation of some results is presented in Figure 1.

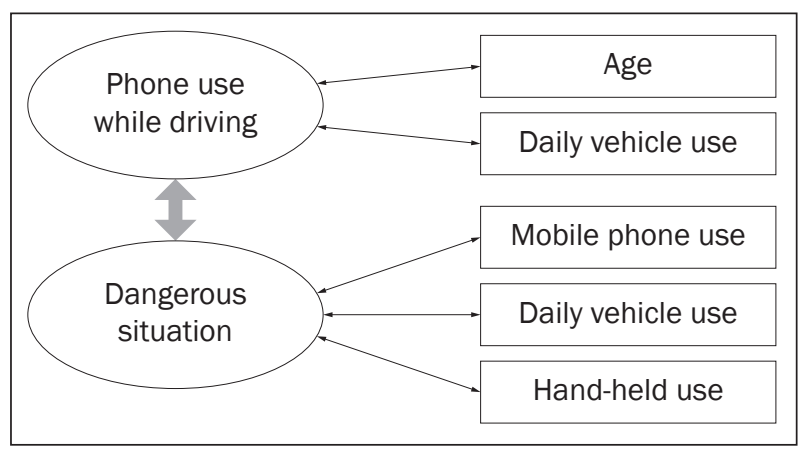

Figure 1 - Graphical representation of some results 


\subsection{Logistic regression analysis results}

Table 1 presents the logistic regression coefficients, standard errors, Wald statistics, significant level and odds-ratios $[\operatorname{Exp}(\beta)]$ for mobile phone use while driving and not dangerous situations while driving. The Wald statistics is used to estimate the significance of relationships between variables. Odds ratios greater than 1 indicate an increase in the likelihood of mobile phone use while driving and not dangerous situation while driving with a one-unit increase in a predictor variable. Odds ratios less than 1 show that odds are less likely with a one-unit change. According to the Wald criterion, age, education level, not using text messaging, break time and driving experience have a significant effect on mobile phone use while driving.

The coefficients $(\beta)$ show that there are negative or inverse relationships, as elementary school graduates and not using text messaging while driving increase, mobile phone use while driving decreases. The odds ratio shows a proportion decrease of 84.8 percent (calculated as 1-0.152 =0.848*100) for elementary school graduates and 80.1 percent for not using text messaging less likely to use phone while driving.

High school education level, mobile phone ownership, daily mobile phone use, daily vehicle use, handsheld mode, the most called person, penalty as a result of mobile phone use while driving, and dangerous or risky situations that they experienced while they were both driving and using mobile phones were not a significant factor in predicting mobile phone use while driving.

For a unit increase in drivers with junior high school education level, the odds for using phone while driving is increased by a factor of 2.98 when all other variables are held constant. Looking at the odds ratios, age was 26.7 percent, break time was 24.1 percent and driving experience was 18.8 percent more likely to use phone while driving.

Wald criterion shows that age, daily mobile phone use, daily vehicle use, hands-held mode, and not a police penalty as a result of mobile phone use while driving have a significant effect on safety while driving. Age increases the odds ratio of not being involved in dangerous situations while driving by 14.4 percent. In other words, drivers have more safety at advanced ages. Safety situation (not involved in dangerous situations) while driving is decreased by 4.8 percent if taxi drivers use more mobile phones in a day, by 17.3 percent if they use more vehicle in a day. Hands-held mobile phone use and dangerous situation in traffic are strongly related. Drivers who use phone in hands-held mode while driving are remarkably 58.5 percent less likely to be involved in safety situations. Having no police penalty because of mobile phone while driving decreases odds of not being involved in a dangerous situation by 44.8 percent. Hands-held mobile phone use $(p<0.001$ and not getting a (traffic penalty) ticket for phone using while driving $(p<0.05)$ predict dangerous situations.

Table 1 - Logistic regression analysis of variables with phone use and safety situation

\begin{tabular}{|c|c|c|c|c|c|c|c|c|c|c|c|c|c|c|}
\hline \multirow{2}{*}{ Variables } & \multicolumn{7}{|c|}{ mobile phone use while driving } & \multicolumn{7}{|c|}{ not a dangerous situation while driving } \\
\hline & $\beta$ & S.E. & Wald & df & Sig & $\mathrm{R}$ & $\operatorname{Exp}(\beta)$ & $\beta$ & S.E. & Wald & df & Sig & $\mathrm{R}$ & $\operatorname{Exp}(\beta)$ \\
\hline AGE & 0.237 & 0.066 & 13.009 & 1 & 0.000 & 0.186 & 1.267 & 0.134 & 0.051 & 6.860 & 1 & 0.009 & 0.104 & 1.144 \\
\hline EDU & & & 24.591 & 3 & 0.000 & 0.242 & & & & 9.569 & 3 & 0.087 & 0.036 & \\
\hline $\mathrm{EDU}(1)$ & -1.885 & 0.629 & 8.979 & 1 & 0.003 & -0.148 & 0.152 & -0.534 & 0.353 & 2.283 & 1 & 0.131 & -0.025 & 0.586 \\
\hline EDU(2) & 1.092 & 0422 & 6.687 & 1 & 0.010 & 0.122 & 2.980 & 0.552 & 0.303 & 3.312 & 1 & 0.069 & 0.054 & 1.736 \\
\hline $\mathrm{EDU}(3)$ & -0.925 & 0.518 & 3.184 & 1 & 0.074 & -0.061 & 0.397 & 0.095 & 0.286 & 0.109 & 1 & 0.741 & 0.000 & 1.099 \\
\hline OWN & -0.029 & 0.110 & 0.069 & 1 & 0.792 & 0.000 & 0.971 & -0.109 & 0.078 & 1.960 & 1 & 0.162 & 0.000 & 0.897 \\
\hline PHOUSE & -0.044 & 0.031 & 1.992 & 1 & 0.158 & 0.000 & 0.957 & -0.049 & 0.021 & 5.345 & 1 & 0.021 & -0.086 & 0.952 \\
\hline SMS(1) & -1.613 & 0.426 & 14.339 & 1 & 0.000 & -0.197 & 0.199 & -0.002 & 0.144 & 0.000 & 1 & 0.988 & 0.000 & 0.998 \\
\hline VECUSE & -0.112 & 0.121 & 0.856 & 1 & 0.355 & 0.000 & 0.895 & -0.190 & 0.068 & 7.843 & 1 & 0.005 & -0.114 & 0.827 \\
\hline BREAK & 0.216 & 0.068 & 9.931 & 1 & 0.002 & 0.158 & 1.241 & -0.065 & 0.046 & 1.961 & 1 & 0.161 & 0.000 & 0.937 \\
\hline HELD(1) & -0.065 & 0.300 & 0.047 & 1 & 0.828 & 0.000 & 0.937 & -0.880 & 0.242 & 13.186 & 1 & 0.000 & -0.157 & 0.415 \\
\hline CALL & & & 2.559 & 2 & 0.278 & 0.000 & & & & & & & & \\
\hline CALL(1) & -0.454 & 0.351 & 1.677 & 1 & 0.195 & 0.000 & 0.635 & & & & & & & \\
\hline CALL(2) & 0.471 & 0.415 & 1.288 & 1 & 0.256 & 0.000 & 1.602 & & & & & & & \\
\hline EXP & 0.172 & 0.064 & 7.206 & 1 & 0.007 & 0.128 & 1.188 & 0.099 & 0.056 & 3.102 & 1 & 0.078 & 0.049 & 1.104 \\
\hline POLICE(1) & 0.650 & 0.362 & 3.217 & 1 & 0.073 & 0.062 & 1.915 & -0.595 & 0.303 & 3.856 & 1 & 0.050 & -0.064 & 0.552 \\
\hline DANGER & -0.355 & 0.214 & 2.757 & 1 & 0.097 & -0.049 & 0.702 & & & & & & & \\
\hline PHODRI(1) & & & & & & & & -0.296 & 0.193 & 2.351 & 1 & 0.125 & -0.028 & 0.744 \\
\hline Constant & -353.84 & 130.33 & 7.371 & 1 & 0.007 & & & -197.18 & 113.41 & 3.023 & 1 & 0.082 & & \\
\hline $\begin{array}{l}\mathrm{R}^{2} \text { (Nagelkerke) } \\
\end{array}$ & \multicolumn{7}{|c|}{0.450} & \multicolumn{7}{|c|}{0.274} \\
\hline $\mathrm{R}^{2}$ (Cox\&Snell) & \multicolumn{7}{|c|}{0.280} & \multicolumn{7}{|c|}{0.205} \\
\hline$-2 \mathrm{LL}$ & \multicolumn{7}{|c|}{210.401} & \multicolumn{7}{|c|}{377.291} \\
\hline$x^{2}$ & \multicolumn{7}{|c|}{$x^{2}=107.211(p=0.000)$ d.f. $=15$} & \multicolumn{7}{|c|}{$x^{2}=75.143(p=0.000)$ d.f. $=13$} \\
\hline
\end{tabular}




\section{DISCUSSION}

The present study examined the use of mobile phones while driving as a risk factor. The first finding was the high rate of mobile phone ownership in the sample. It was also found that mobile phone use (hand-held or hands-free) is a widespread activity among almost all taxi drivers. Work-related reasons may be powerful factors in explaining high levels of phoning while driving. Work-related mobile phone use as a predicted factor while driving has already been highlighted by Troglauer et al. (2006) and Brusque and Alauzet (2008) [8, 21]. The current research found that $81 \%$ of the taxi drivers reported that they are using hand-held phone in traffic. This finding is a bit surprising as using a hand-held mobile phone while driving is illegal in Turkey. In other words, this result apparently shows that most of the taxi drivers in Turkey are currently ignoring the law. This is a common problem for other countries in which most drivers use a hand-held mobile phone while driving [3, 23, 40]. The study identified that one-third of taxi drivers read or write text-messages while driving. Text-messaging rate found by Gras et al. (2007) was 27\% among the sample of Spanish university workers [40]. In another study [39], 100.0\% of the group reported talking and $72.5 \%$ of participants reported text-messaging on a cellular phone while driving at least some of the time. The study also found that disuse of SMS reduces risk of using phone while driving by $80.1 \%$.

It is obvious in the present study that, as in other studies [2, 3, 39, 41, 42], age is one of the main explanatory factors of mobile phone use while driving which continues at a high rate especially among the youngest drivers since they tend to be the heaviest adopters of mobile phones and other new telecommunication technologies. Previously, Brusque and Alauzet (2008) reported age as the main factor of phoning while driving for the male population only [8].Although the most extensive users of mobile phones while driving are the younger group of taxi drivers, according to the $\mathrm{X}^{2}$-test, no significant relationship was found between age and experiencing a dangerous situation during phoning while driving. Similar result was reported in a previous research [43] that age is not a significant factor in the relationship between mobile phone use and driving safety. However, this idea contradicts the finding which implies that age is a strong determinant of phone-related hazards concerning the use of phone in traffic while driving [3]. Similar to this study the results of logistic regression show that age was 26.7 more likely to use phone while driving and increases ratio of safety situations while driving by 14.4 .

The results of this research show that safety situation (not involved in dangerous situations) while driving is decreased by 17.3 percent if taxi drivers use vehicle more in a day. The $x^{2}$-test suggests a significant relationship between phoning while driving and driving mileages. This finding is consistent with previous research [8] which identified high mileage as the main explanatory factor of phoning while driving for females. The present study also found that police penalty as result of phoning while driving had not a significant impact on taxi drivers' decision about phoning while driving. But absence of penalty decreases odds of safety (not involving dangerous situations) by 44.8 percent.

The current study suggested that phoning while driving has an effect on traffic safety. More than half of the taxi drivers who used a mobile phone while driving reported that they had experienced dangerous situations while phoning and driving. Lamble et al. (2002) and Pöysti et al. (2005) found similar results that about $50 \%$ of the private drivers in their sample had experienced dangerous situations because of mobile phone use $[3,44]$. In a previous study only $6 \%$ of the truck drivers reported to have caused dangerous situations because of mobile phone use; however, $66 \%$ of the sample reported experiencing dangerous situations because of other road users' mobile phone use [21]. The time period people use the phone each day significantly affects the traffic safety. A taxi driver who spent longer periods on the phone while driving would therefore be at greater risk of being involved in a dangerous situation than someone who phones while driving for much shorter periods. Safety (not involved in dangerous situations while driving) is decreased by 4.8 percent if taxi drivers use more mobile phone in a day. This self-reported finding is supported by some studies which found there was a significant correlation between frequencies of mobile phone use or the daily mobile phone use time and the risk of being involved in a crash $[3,40]$. In the current study the taxi drivers reported that they had experienced more dangerous situations while using hand-held phones than using hands-free ones. Use of phones in hands-held mode while driving decreases safety situations by 58.5 percent. It can be realized as an evidence for the result that talking over a hand-held phone is strongly related to dangerous situations in traffic. As the self-reported finding of this study, common sense suggests that hands-free phones are safer than hand-held phones while driving, but hands-free phone would not provide any safety advantage over the hand-held phone $[6,11$, $22,31,35]$.

\section{Limitation}

There are a number of possible limitations with this study. First, this study suffers from the usual perceived weaknesses associated with self-reported data. It is reliant on the respondents remembering the situation. The number of actual dangerous situations caused by using mobile phone while driving might be higher or lower than reported. Self-reported data are also seri- 
ously affected by social desirability bias. People might over- or under-estimate their level of mobile phone use when compared to their actual calling records. In addition to this, driver's criteria about what is a dangerous situation may differ between different driver groups. For example, younger or more skilled drivers, unlike older drivers, may not consider some situations as dangerous. Also, in this study the assumption of traffic safety issue was based on the self-report of dangerous situations. The second possible limitation due to the use of self-reported data is the under-reporting risk of illegal practices such as hand-held phone use while driving. Some respondents may conceal or minimize the fact about their actual behaviour which is banned by law. Another limitation is the possibility that results differ significantly from the general population in some ways due to the sample of this study.

\section{CONCLUSION}

Mobile phones have become a major source of communication during the last 20 years. Parallel with this continuous increase in the number of mobile phone users, the number of drivers using mobile phones while driving has also increased. One of the important results of this research is that the level of phone use while driving is very high. The present study highlights the increasing risk for traffic safety caused by mobile phone use while driving. The findings of the study suggest some consequences in developing preventive policy about accident risk. It is clear that mobile phone use while driving will continue to be an increasingly important traffic safety issue. Whatever the reason for using phone while driving, driver education programs, public information and continuous law enforcements are very important factors to determine and control this potential risk for traffic safety.

MURAT DARÇIN,Dr.

E-mail:mrtdrc@yahoo.com

MURAT ALKAN,Dr.

E-mail: muratalkan95@yahoo.com

içişleriBakanlığı

06650 Ankara, Türkiye

\section{ÖZET}

\section{SÜRÜŞ ESNASINDA CEP TELEFONU KULLANMANIN GÜVENLIK RISKI, TAKSI SÜRÜCÜLERI ÖRNEĞi}

Önceki araştırmalar göstermektedir ki, sürüş esnasında cep telefonu kullanmak bir kazaya karışma riskini artırmaktadır. Bu çalışma, taksi sürücülerinin cep telefonu kullanma sıklığını ve sürüş esnasında telefon kullanmanın trafik güvenliğine etkisini araştırmaktadır. Çalışma için uzman anketörler tarafından bir grup taksi sürücüsüne görüşme temelli anket uygulandı. Taksi sürücülerinin beyanına göre \%81'i sürüş esnasına cep telefonu kullanmaktadır. Sürüş esnasında cep telefonu kullanma ile sürücülerin kendi if- adelerine göre tehlikeli bir durumla karşılaşmaları arasında bir ilişki bulunmuştur. Şu açıktır ki, sürüş esnasında cep telefonu kullanmak önemli bir trafik güvenliği konusudur.

\section{ANAHTAR KELIMELER}

tehlikeli durum; cep telefonu; risk alma; profesyonel sürücüler; güvenlik;

\section{REFERENCES}

[1] Information Technologies and Communication Authority. Turkish electronic communications market, quarterly market data report 2009 [Internet, cited 2011 Dec 19]. Available from: http://www.tk.gov.tr/Yayin/pv/ ucaylik09_3.pdf.

[2] Sullman MJM,Baas PH. Mobile phone use amongst New Zealand drivers. Transportation Research Part F. 2004;7(2):95-105.

[3] Pöysti L, Rajalin S,Summala H. Factors influencing the use of cellular (mobile) phone during driving and hazards while using it. Accident Analysis and Prevention. 2005;37(1):47-51.

[4] Svenson O, Patten CJD. Mobile phones and driving: a review of contemporary research. Cognition, Technology and Work. 2005;7:182-197.

[5] Eby DW, Vivoda JM,Louis StRM. Driver hand-held cellular phone use: a four-year analysis. Journal of Safety Research. 2006;37(3):261-265.

[6] McCartt AT, Hellinga LA,Geary LL. Effects of Washington, D.C, law on drivers' hand-held cell phone use. Traffic Injury Prevention. 2006;7:1-6.

[7] Townsend M. Motorists' use of hand held cell phones in New Zealand: an observational study. Accident Analysis and Prevention. 2006;38(4):748-750.

[8] Brusque C,Alauzet A. Analysis of the individual factors affecting mobile phone use while driving in France: Socio-demographic characteristics, car and phone use in professional and private contexts. Accident Analysis and Prevention. 2008;40:35-44.

[9] Barkana Y, Zadok D, Morad Y, Avni I. Visual field attention is reduced by concomitant hands-free conversation on a cell telephone. American Journal of Ophthalmology. 2004;138:347-353.

[10] Lesch MF, Hancock PA. Driving performance during concurrent cell phone use: Are drivers aware of their performance decrements? Accident Analysis and Prevention. 2004;36:471-480.

[11] McCartt AT, Hellinga LA,Braitman KA. Cell phones and driving: review of research. Traffic Injury Prevention. 2006;7:89-106.

[12] Foss RD, Goodwin AH, McCartt AT,Hellinga LA. Shortterm effects of a teenage driver cell phone restriction. Accident Analysis and Prevention. 2009;41:419-424.

[13] Treffner PJ, Barret R. Hands-free mobile phone speech while driving degrades coordination and control. Transportation Research Part F. 2004;7:229-246.

[14] Mccarley JS, Vais MJ, Pringle H, Kramer AF, Irwin DE, Strayer DL. Conversation disrupts change detection in complex traffic scenes. Human Factors. 2004;46(3):424-436.

[15] Beede KE,Kass SJ. Engrossed in conversation: the im- 
pact of cell phones on simulated driving performance. Accident Analysis and Prevention. 2006;38:415-421.

[16] Patten CJD, Kirchner A, Ostlund J,Nilsson L. Using mobile telephones: cognitive workload and attention resource allocation. Accident Analysis and Prevention. 2004;36(3):341-350.

[17] Harbluk JL, Noy Yl, Trobvich PL,Eizenman M. An onroad assessment of cognitive distraction: impacts on drivers' visual behavior and braking performance. Accident Analysis and Prevention. 2007;39:373-379.

[18] Maples WC, DeRosier W, Hoenes R, Bendure R, Moore $\mathrm{S}$. The effects of cell phone use on peripheral vision. Optometry. 2008;79:36-42.

[19] Strayer DL,Drews FA. Profiles in driver distraction: effects of cell phone conversations on younger and older drivers. Human Factors. 2004;46(4):640-649.

[20] Horrey WJ,Wickens CD. The impact of cell phone conversations on driving using meta-analytic techniques. Human Factors. 2006;48(1):196-205.

[21] Troglauer T, Hels T,Christens PF. Extent and variations in mobile phone use among drivers of heavy vehicles in Denmark. Accident Analysis and Prevention. 2006;38:105-111.

[22] Caird JK, Willness CR, Steel P,Scialfa C. A meta-analysis of the effects of cell phones on driver performance. Accident Analysis and Prevention. 2008;40:12821293.

[23] Wogalter MS,Mayhorn CB. Perceptions of driver distraction by cellular phone users and nonusers. Human Factors. 2005;47(2):455-467.

[24] McEvoy SP, Stevenson MR,Woodward M. Phone use and crashes while driving: a representative survey of drivers in two Australian states. Medical Journal of Australia. 2006;185:630-634.

[25] Walsh SP,White KM. Ring, ring, why did I make that call? Beliefs underlying Australian university students' mobile phone use. Youth Studies Australia. 2006;25:49-57.

[26] Walsh SP, White KM, Hydea MK,Watson B. Dialling and driving: Factors influencing intentions to use a mobile phone while driving. Accident Analysis and Prevention. 2008;40:1893-1900.

[27] Helmick DO, Farrow JA, Padilla MJ,Augusta GM. Driver Distractions and Inattention-Data Summary.Department of California Highway Patrol; 2002.

[28] Laberge-Nadeau C, Maag U, Bellavance F, Lapierre SD, Desjardins D,Messier S, et al. Wireless telephones and the risk of road crashes.Accident Analysis and Prevention. 2003;35:649-660.

[29] Violanti JM, Marshall JR. Cellular phones and traffic accidents: An epidemiological approach. Accident Analysis and Prevention. 1996;28:265-270.
[30] Violanti JM. Cellular phones and fatal traffic collisions. Accident Analysis and Prevention. 1998;30:519-524.

[31] McEvoy SP, Stevenson MR, McCartt AT, Woodward M, Haworth C, Palamara P,Cercarelli R. Role of mobile phones in motor vehicle crashes resulting in hospital attendance: a case-crossover study. British Medical Journal. 2005;331(7514):428-430A.

[32] Redelmeier DA, Tibshirani RJ. Association between cellular-telephone calls andmotor vehicle collisions. New England Journal of Medicine. 1997;336(7):453-458.

[33] Redelmeier DA, Tibshirani RJ. Car phones and car crashes: some popular misconceptions. Canadian Medical Association Journal. 2001;164:1581-1582.

[34] White MP, Eiser JR,Harris PR. Risk perceptions of mobile phone use while driving. Risk Analysis. 2004;24(2):323-334

[35] Consiglio W, Driscoll P, Witte M,Berg WP. Effect of cellular telephone conversations and other potential interference on reaction time in a braking response.Accident Analysis and Prevention. 2003;325:495-500.

[36] Törnros JEB, Bolling AK. Mobile phone use: effects of handheld and handsfree phones on driving performance. Accident Analysis and Prevention. 2005;37(5):902-909.

[37] Törnros JEB,Bolling AK.Mobile phone use - effects of conversation on mental workload and driving speed in rural and urban environments. Transportation Research Part F. 2006;9:298-306.

[38] Hatfield J,Murphy S. The effects of mobile phone use on pedestrian crossing behaviour at signalised and unsignalised intersections. Accident Analysis and Prevention. 2007;39:197-205.

[39] Nelson E, Atchley P, Little TD. The effects of perception of risk and importance of answering and initiating a cellular phone call while driving. Accident Analysis and Prevention. 2009;41:438-444.

[40] Gras ME, Cunill M, Sullman MJM, Planes M, Aymerich M,Font-Mayolas S. Mobile phone use while driving in a sample of Spanish university workers. Accident Analysis and Prevention. 2007;39:347-355

[41] Pennay D. Community Attitudes to Road Safety: Community Attitudes Survey Wave 18, 2005 (No. CR 227). Australian Transport Safety Bureau; 2006.

[42] Lee JD. Technology and teen drivers.Journal of Safety Research. 2007;38:203-213.

[43] Chen Y-L. Driver personality characteristics related to self-reported accident involvement and mobile phone use while driving. Safety Science. 2006;45(8):823831.

[44] Lamble D, Rajalin S, Summala H. Mobile phone use while driving: public opinions on restriction. Transportation. 2002;29:223-236. 